Available online on 15.07.2018 at http://jddtonline.info
Journal Of Drug Delivery and Therapeutics
$\begin{gathered}\text { Open Access to Pharmaceutical and Medical Research } \\ \text { 2011-18, publisher and licensee JDDT, This is an Open Access article which permits unrestricted non- } \\ \text { commercial use, provided the original work is properly cited }\end{gathered}$

Open $\odot$ Access

Research Article

\title{
FORMULATION OPTIMIZATION AND EVALUATION OF GASTRORETENTIVE TABLETS OF ONDANSETRON HCL
}

\author{
Dr. Siraj N Shaikh*, Band Afzal Abdul Razzak, Dr. G. J. Khan \\ Department of Pharmaceutics, Ali-Allana College of Pharmacy Akkalkuwa, Nandurbar, Maharashtra, India
}

\begin{abstract}
The aim of the work is to design Gastroretentive tablets of Ondansetron $\mathrm{HCl}$ for gastric retention by using $3^{2}$ factorial designs. Floating tablets of Ondansetron $\mathrm{HCl}$ were prepared by direct compression method using polymers, sodium alginate and excipient. Gastroretentive tablets of Ondansetron $\mathrm{HCl}$ were successfully prepared by effervescent technique using different gel forming polymers- HPMC K200M, and sodium alginate. Formulation was optimized by design expert software. Floating tablets were evaluated for floating time, floating lag time, drug content, raft measurement and in vitro dissolution profile. The lag time is between $17-22 \mathrm{sec}$ and floating time of the formulations for $12 \mathrm{hrs}$. The best fit model is Korsemeyer Peppas Model. From the study it is proof that the sustain release by floating tablets of Ondansetron $\mathrm{HCl}$ can be develop. Optimized batch selected was A3, The prepared gastroretentive test formulation was found to exhibit satisfactory physico-chemical characteristics at the end of 3 months, during the stability studies. The optimized formulation A3 was found to be stable at $40^{\circ \mathrm{C}} / 75 \% \mathrm{RH}$.
\end{abstract}

Keywords: Gastric retention time, Ondansetron $\mathrm{HCl}$, HPMC, sodium alginate, measurement of raft, Factorial design, stability studies.

Article Info: Received 07 April, 2018; Review Completed 03 June 2018; Accepted 03 June 2018; Available online 15 July 2018

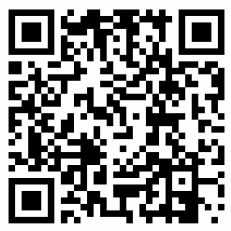

Cite this article as:

Shaikh SN, Razzak BAA, Khan GJ, Formulation optimization and evaluation of gastroretentive tablets of ondansetron $\mathrm{HCl}$, Journal of Drug Delivery and Therapeutics. 2018; 8(4):185-195 DOI: http://dx.doi.org/10.22270/iddt.v8i4.1763

*Address for Correspondence:

Dr. Shaikh Siraj N, Head Department of Pharmaceutics, Ali-Allana College of Pharmacy Akkalkuwa, Nandurbar, Maharashtra, India.

\section{INTRODUCTION}

Oral delivery of drug is the most preferred route of drug delivery due to ease of administration, patient compliance \& flexibility in formulation. Conventional oral dosage forms achieve as well as maintain drug concentration within therapeutically effective range needed for treatment only when taken several times a day.It is having low bulk density that have sufficiently buoyancy to float over the gastric contents and remain buoyant in the Gastric juice of stomach without affecting the gastric emptying rate for a prolonged period of time ${ }^{1}$. Bioavailability $^{1,2}$.

\section{Raft forming system:}

This system focus more for delivery of antacid and delivery of drugs used to treat gastrointestinal infection and disorders. The basic mechanism involves formation of viscous cohesive gel when the system comes in contact with gastric fluid. In this each portion of liquid swells and forms a continuous layer of gel known as raft. The raft floats because of buoyancy created by formation of $\mathrm{CO} 2$. This raft acts as a physical barrier to prevent the reflex of gastric content into the esophagus. This raft forming system contains a gel forming agent and alkaline bicarbonates or carbonates which is responsible for making the system less dense than the gastric fluid and to float on the gastric fluid ${ }^{3,4}$.

Effect of sodium bicarbonate on the drug release from raft forming system:

Sodium bicarbonate is used as a gas generating agent. Gas generating agent sodium bicarbonate interacts with the gastric acid and generates carbon dioxide which gets entrapped within the swellable matrix. Carbonate or bicarbonate may be present in the amount ranges from 
$5 \%$ to $50 \%$ and preferably from about $10 \%$ to $30 \%$ by weight of composition. Increasing the concentration of bicarbonate decreases the floating lag time because of faster and higher carbon dioxide generation. At higher concentration of effervescent agent, coating of the tablet becomes less stable. This is because of increase in the internal pressure and there by rupturing the polymer coating which ultimately results in sudden increase in drug release $\mathrm{s}^{5,6,7}$.

Therefore the present study is planned to formulate \& evaluate floating tablet of Ondansetron hydrochloride using HPMC K200M \&HPMC K4M polymers, sodium alginate \& excipients. Floating drug delivery systems have an efficient means of enhancing the bioavailability and controlled delivery of many drugs. Dosage forms with a prolonged GRT will bring about new and important therapeutic options. The data obtained thus suggests that floating delivery system of Ondansetron hydrochloride can be successfully designed to give controlled drug delivery and improved oral bioavailability.

\section{MATERIALS AND METHODS}

Ondansetron HCl, HPMC K-200 M, HPMC K-4 M, Sodium Bicarbonate, Citric Acid, Magnesium Stearate, Talc, Lactose, Sodium Alginate And Avicle-101.

For study purpose, 9 formulations with different excipient were prepared as shown in table 1. Mixture passed through the sieve for purpose of uniformity of particle and remaining particle again triturated and mixed. Floating tablet was prepared by dry compression method. The tablet was compressed using ( $9 \mathrm{~mm}$ punch) set in a compression machine.

Table 1: Optimization batches design

\begin{tabular}{|c|c|c|c|c|c|c|c|c|c|}
\hline \multirow[b]{2}{*}{ Ingredients } & \multicolumn{8}{|c|}{ Formulation batch code } & \multirow[b]{2}{*}{ A9 } \\
\hline & A1 & A2 & A3 & A4 & A5 & A6 & A7 & A8 & \\
\hline Ondansetron $\mathrm{Hcl}$ & 20 & 20 & 20 & 20 & 20 & 20 & 20 & 20 & 20 \\
\hline HPMC K-200 M & 30 & 30 & 30 & 40 & 40 & 40 & 50 & 50 & 50 \\
\hline HPMC K-4 M & 20 & 30 & 40 & 20 & 30 & 40 & 20 & 30 & 40 \\
\hline Sodium alginate & 30 & 30 & 30 & 30 & 30 & 30 & 30 & 30 & 30 \\
\hline Sodium bicarbonate & 45 & 45 & 45 & 45 & 45 & 45 & 45 & 45 & 45 \\
\hline Citric acid & 15 & 15 & 15 & 15 & 15 & 15 & 15 & 15 & 15 \\
\hline Talc & 05 & 05 & 05 & 05 & 05 & 05 & 05 & 05 & 05 \\
\hline Magnesium stearate & 05 & 05 & 05 & 05 & 05 & 05 & 05 & 05 & 05 \\
\hline Lactose Q.S. & 80 & 70 & 60 & 70 & 60 & 50 & 60 & 50 & 30 \\
\hline Total & 250 & 250 & 250 & 250 & 250 & 250 & 250 & 250 & 250 \\
\hline
\end{tabular}

\section{Evaluation Parameters:}

\section{Pre-compression evaluation parameters:}

Angle of repose, bulk density, tapped density,carr's index and hausner's ratio were evaluated to determine the flow property of the prepared powder mixture.

\section{Post- compression evaluation parameters:}

\section{Thickness:}

Thickness was measured using a vernier caliper. Five tablets of the formulation were picked randomly and thickness was measured individually.

\section{Hardness:}

Hardness was measured using Monsanto hardness tester. The hardness expressed in $\mathrm{kg} / \mathrm{cm} 2$. For each batch three tablets were tested.

\section{Friability:}

Twenty tablets were weighed and placed in the Roche friabilator and apparatus was rotated at $25 \mathrm{rpm}$ for 4 minutes. After revolutions, the tablets were deducted and weighed again. The percentage friability was measured using formula,

$\% \mathrm{~F}=\{1-(\mathrm{Wt} . / \mathrm{W})\} \times 100$

Where, $\% \mathrm{~F}=$ Friability in percentage

$\mathrm{W}=$ Initial weight of tablets
Wt. = Weight of tablets after revolution

\section{Weight variation:}

Twenty tablets were randomly selected from each batch and individually weighed. The average weight and standard deviation of 20 tablets was calculated. The batch passes the test for weight variation test if not more than two of the individual tablet weight deviate from the average weight.

\section{Drug Content Uniformity:}

Ten tablets for each batch was taken and triturated. Powder equivalent to $20 \mathrm{mg}$ of drug was weighed and was transferred to breaker and $0.1 \mathrm{~N} \mathrm{HCl}$ was added and it was then shaken for $5 \mathrm{~min}$ and finally $0.1 \mathrm{~N} \mathrm{HCl}$ was added to make the volume up to $100 \mathrm{ml}$ and solution was then sonicated for $15 \mathrm{~min}$ and filtered through Whatman filter paper. Finally, a solution was diluted suitably and the absorbance of the resultant solution was measured to determine the drug content spectrophotometrically at $310 \mathrm{~nm}$ using UV/Visible spectrophotometer Shimadzu 1800 against $0.1 \mathrm{~N} \mathrm{HCl}$ blank.

\section{In-vitro Buoyancy Studies:}

The in-vitro buoyancy was determined by floating lag time. The time required for the tablet to rise to the surface and float was determined as floating lag time. In 
this the tablets were placed in $100 \mathrm{ml}$ beaker containing $0.1 \mathrm{~N}$ HCL.

\section{Swelling index study:}

For each formulation batch, one tablet was weighed and placed in a beaker containing $200 \mathrm{ml}$ of buffer media. After each interval the tablet was removed from beaker and weighed again up to $12 \mathrm{~h}$. The swelling index was calculated using following formula.

Swelling index $($ S.I $)=\{($ wt-wo $) /$ WO $\} \times 100$

Where, S.I. = Swelling index

Wt. $=$ Weight of tablet at time $\mathrm{t}$

$\mathrm{WO}=$ Weight of tablet before placing in the Beaker.

\section{Raft strength measurement}

1. A tablet powder equivalent to unit dose was transferred to $150 \mathrm{ml}$ of $0.1 \mathrm{~N} \mathrm{HCl}$ and maintained at $37^{\circ} \mathrm{C}$ in a $250 \mathrm{ml}$ glass beaker.

2. Each raft was allowed to form around an L-shaped wire probe (Height $9 \mathrm{~cm}$ and wide at bottom surface $2 \mathrm{~cm}$ ) held upright in the beaker throughout the whole period (30 min) of raft development.

3. Raft strength was estimated using the modified balance method.

4. Water was added drop wise to the left sided beaker and the weight of water required to break the raft was recorded.

\section{Raft weight and raft volume measurement}

1. Raft volume and raft weight Rafts were calculated by taking unit dose for $30 \mathrm{~min}$ in glass beakers of $150 \mathrm{ml} 0.1 \mathrm{~N} \mathrm{HCl}$ but without the inclusion of a wire probe.

2. Each beaker used for raft formation was reweighed (W1).

3. Note the volume of beaker before formation of raft. (M1).

4. The position to which the top of each raft reached was marked on the outside of the beaker.

5. The total weight of the beaker and contents was obtained after raft development (W2).

6. The weight of each raft was then calculated from the formula:

Raft weight $=$ Total weight of the beaker and contents was obtained after raft development (W2) - Preweighed beaker used for raft formation (W1).

1. The raft was then removed from the beaker by carefully decanting off the liquid and tipping the raft into a pre-tarred plastic weighing petri plate.

2. This was left to stand for $30 \mathrm{~s}$, excess subnatant liquid was drained off and the raft was weighed (W3).
3. Remaining liquid was removed from the inside of the beaker with a paper towel and it was then refilled with water to the marked position (M2).

4. Finally beaker was weighed (W4).

5. The volume of each raft was then calculated from the formula:

Raft volume $=$ Final volume of $0.1 \mathrm{~N} \mathrm{HCl}$ after formation of raft (M2) -Initial volume of $0.1 \mathrm{~N} \mathrm{HCl}$ before formation of raft (M1)Where raft volume is measured in $\mathrm{ml}$. and all weights are measured in gm.

The formula assumes that the density of the subnatant liquid is the same as that of water.

\section{Acid neutralization capacity}

1) A tablet powder equivalent to unit dose was transferred to a $250 \mathrm{ml}$ beaker; $50 \mathrm{ml}$ of water was added to it and was mixed on a magnetic stirrer for 1 min.

2) A $30-\mathrm{ml}$ volume of $1.0 \mathrm{~N} \mathrm{HCl}$ was added with continued stirring on the magnetic stirrer for $10 \mathrm{~min}$ after addition of the acid.

3) Stirring was discontinued briefly and the gum base was removed using a long needle without delay.

4) The needle was promptly rinsed with $20 \mathrm{ml}$ of water, and the washing was collected in the beaker; stirring was resumed for $5 \mathrm{~min}$.

5) Titration was begun immediately. Excess $\mathrm{HCl}$ was titrated against $0.5 \mathrm{~N}$ sodium hydroxide to attain a stable $\mathrm{pH}$ of 3.5 .

6) The number of mEq of acid consumed by the tablet tested was calculated by the following formula:

Total $\mathrm{mEq}=(30 \times \mathrm{N} \mathrm{HCL})-(\mathrm{V} \mathrm{NaOH} \times \mathrm{N} \mathrm{NaOH})$

Where, $\mathrm{N} \mathrm{HCI}=$ Normality of $\mathrm{HCl} ; \mathrm{V} \mathrm{NaOH}=$ Volume of $\mathrm{NaOH}$ required; and $\mathrm{N} \mathrm{NaOH}=$ Normality of $\mathrm{NaOH}$.

\section{In Vitro Dissolution Studies:}

In-vitro drug release studies of the prepared floating tablets were conducted for a period of $12 \mathrm{hrs}$. Using USP type II apparatus (paddle) at $37 \pm 0.5^{\circ} \mathrm{C}$ and at 50 $\mathrm{rpm}$ speed at $\mathrm{pH}$ 1.2. After withdrawing, the samples were analyzed by a UV spectrophotometer at $310 \mathrm{~nm}$.

\section{Stability studies of optimized formulation:}

\section{Procedure:}

In the present study, stability studies were carried out at room temperature $40 \pm 20^{\circ} \mathrm{C}$ and $75 \pm 5 \% \mathrm{RH}$ for a specific time period up to 3 Months for selected formulations. For stability study, the tablets were sealed in aluminium packaging coated inside with polyethylene. 


\section{RESULTS AND DISSCUSSION}

\section{FT-IR Study of Drug}

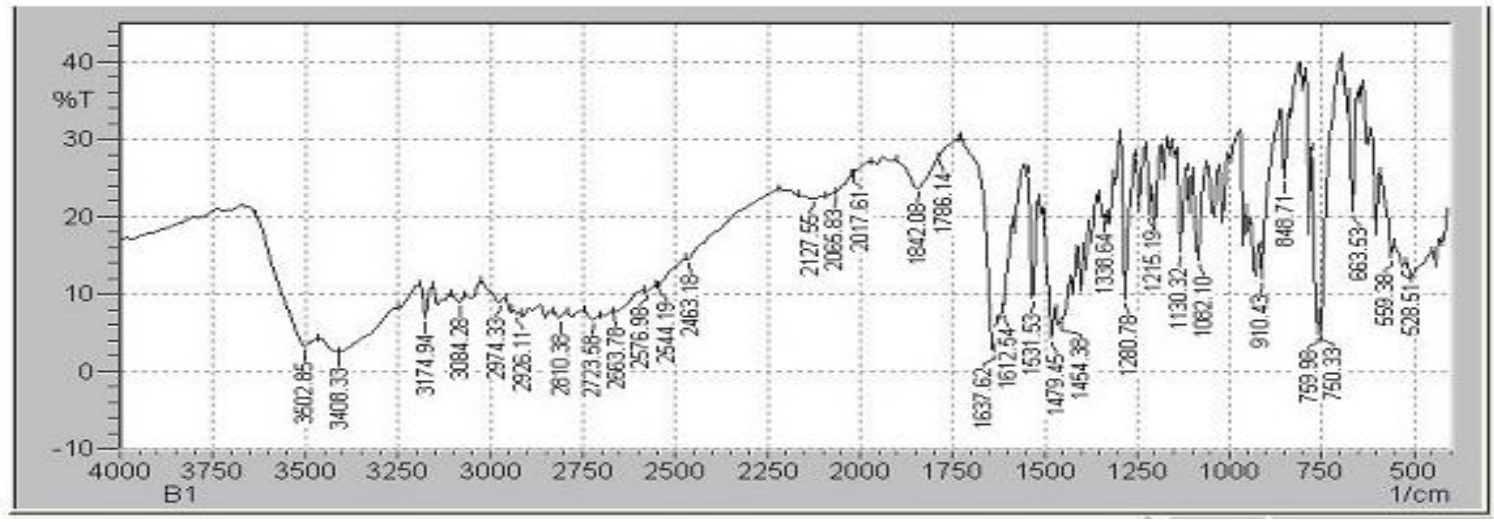

Figure 1: FT-IR spectra of Ondansetron HCl.

Table 2: Interpretation of FT-IR spectra of Ondansetron HCl (pure drug)

\begin{tabular}{|c|c|c|c|}
\hline Sr. No & Functional group & ${\text { Characteristic peaks } \mathbf{~ c m}^{-1}}^{-1}$ & ${\text { Observed peaks } \mathbf{~ c m}^{-1}}^{-1}$ \\
\hline 1 & N-H & $\mathbf{3 0 0 0 - 3 7 0 0}$ & $\mathbf{3 5 0 2 . 8 5}$ \\
\hline 2 & C-H & $\mathbf{2 7 0 0 - 3 3 0 0}$ & $\mathbf{2 8 1 0 . 3 8}$ \\
\hline 3 & C=O & $\mathbf{1 6 0 0 - 1 9 0 0}$ & $\mathbf{1 6 3 7 . 6 2}$ \\
\hline 4 & C=N & $\mathbf{1 6 0 0 - 1 9 0 0}$ & $\mathbf{1 6 1 2 . 5 4}$ \\
\hline 5 & C-H & $\mathbf{1 3 0 0 - 1 5 0 0}$ & $\mathbf{1 3 3 8 . 6 4}$ \\
\hline 6 & C-C & $\mathbf{8 0 0 - 1 2 0 0}$ & $\mathbf{9 1 0 . 4 3}$ \\
\hline
\end{tabular}

\section{FTIR Spectra of Ondansetron HCl (Pure Drug).}

The IR spectrum of pure drug was found to be similar to the reference standard IR Spectrum of Ondansetron $\mathrm{HCl}$ given in Indian pharmacopoeia. The IR Spectrum value of Odansetron $\mathrm{HCl}$ shown in table 2.

\section{Drug - Excipient Compatibility Studies}

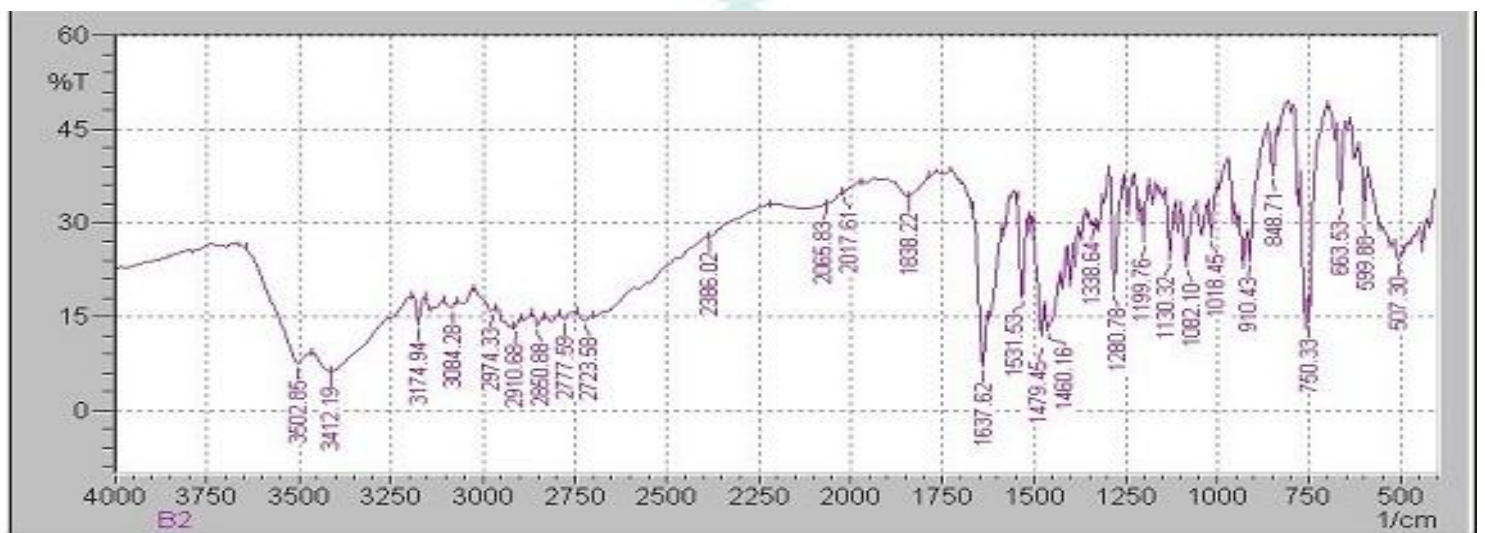

Figure 2: FT-IR spectra of Drug + HPMC K200 M

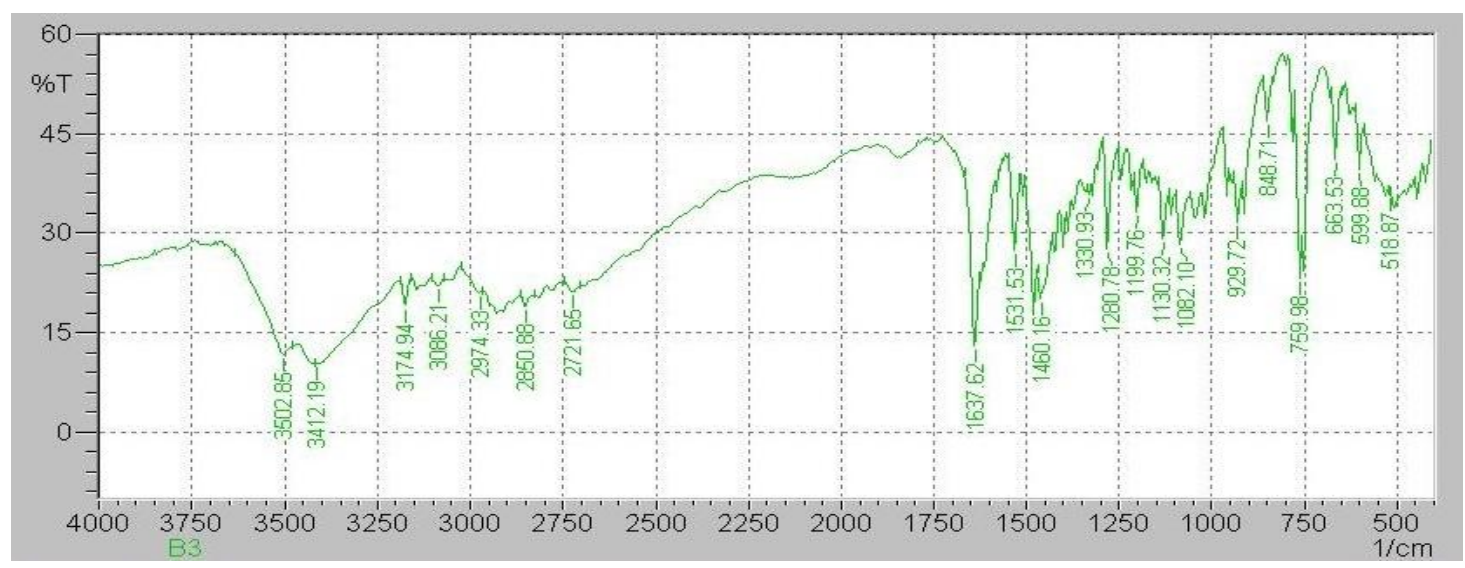

Figure 3: FT-IR spectra of Drug + HPMC K4 M 


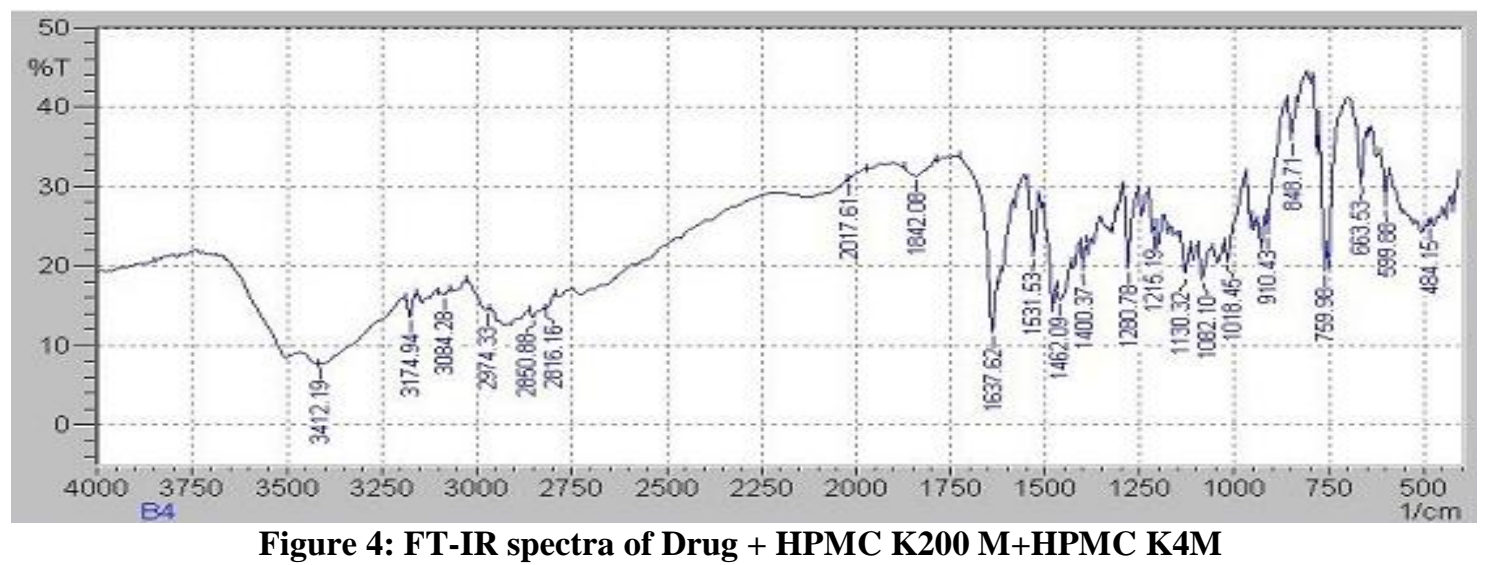

\section{Drug - Excipient Compatibility Studies}

Compatibility studies of pure drug Ondansetron $\mathrm{HCl}$ with polymers were carried out prior to the preparation of tablets. IR spectra of pure drug Ondansetron $\mathrm{HCl}$ and that of with polymerswere obtained, which are shown in figure No.1 to Figure No.4 All the characteristic peaks of Ondansetron $\mathrm{HCl}$ were present in spectra thus indicating compatibility between drugs. It shows that there was no significant change in the chemical integrity of the drug.

DSC OF Ondansetron $\mathrm{HCl}$ : differential scanning calorimetric (DSC)

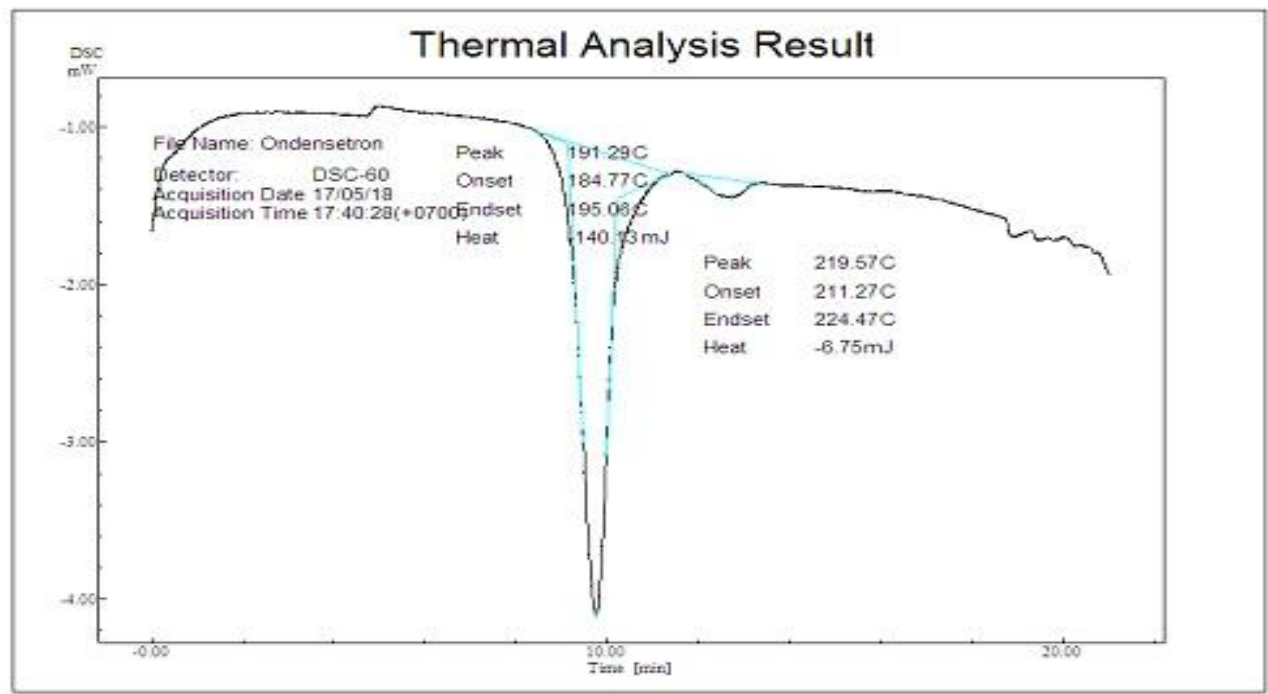

Figure 5: Differential Scanning Calorimetry Ondansetron HCL

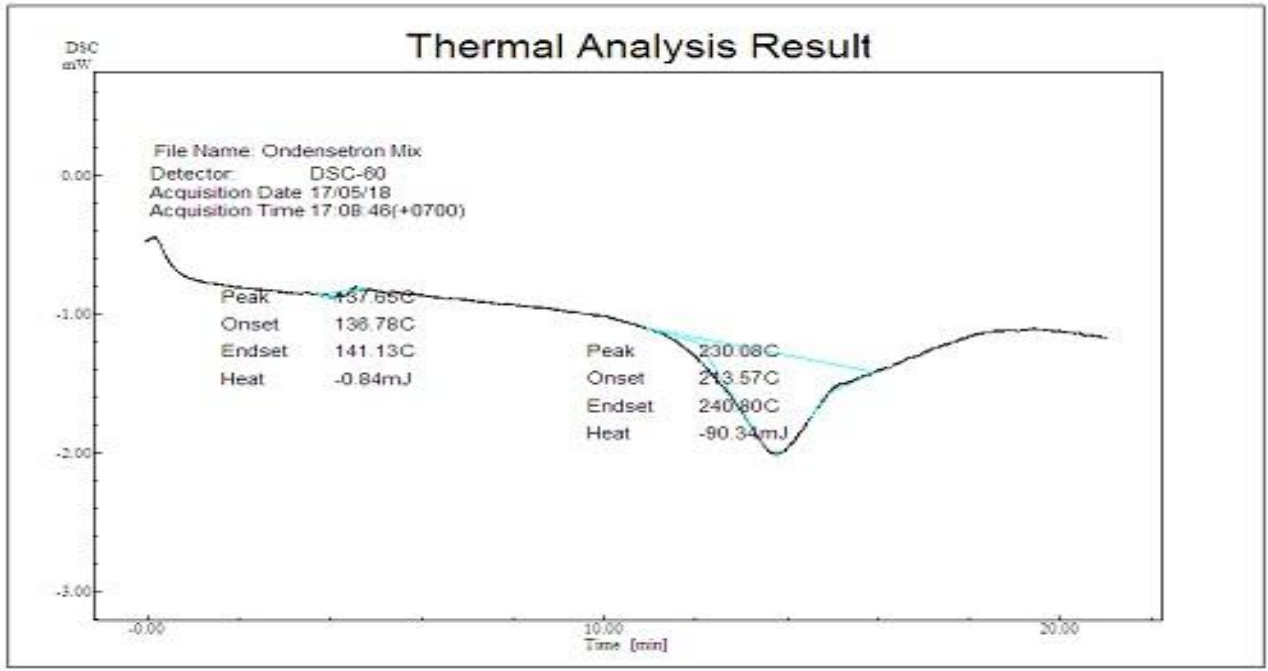

Figure 6: DSC of Ondansetron HCl with Excipients

Studies were carried out using DSC 60, having TA60 software, shimadzu, and Japan. Accurately weight sample were placed on aluminum plate, sealed with aluminum lid and heated at a constant rate $5{ }^{\circ} \mathrm{C} / \mathrm{min}$ over a temperature rang 0 to $250{ }^{0} \mathrm{C}$. Ondansetron $\mathrm{HCl}$ showed in figure $5 \& 6$. 
Table 3: Pre Compression Parameter optimized batches:

\begin{tabular}{|c|c|c|c|c|c|}
\hline $\begin{array}{c}\text { Batch } \\
\text { No. }\end{array}$ & $\begin{array}{c}\text { Angle 0f } \\
\text { Repose }(\boldsymbol{\theta})\end{array}$ & $\begin{array}{c}\text { Bulk Density } \\
(\mathbf{g m} . / \mathbf{m l})\end{array}$ & $\begin{array}{c}\text { Tapped Density } \\
\mathbf{( g m . / m l )}\end{array}$ & Hausner's Ratio & $\begin{array}{c}\text { Carr's Index } \\
\mathbf{( \% )}\end{array}$ \\
\hline A1 & $29.68 \pm 0.46$ & $0.728 \pm 0.02$ & $0.823 \pm 0.005$ & $1.12 \pm 0.02$ & $11.21 \pm 0.02$ \\
\hline A2 & $30.96 \pm 0.01$ & $0.684 \pm 0.01$ & $0.782 \pm 0.001$ & $1.14 \pm 0.02$ & $12.53 \pm 0.02$ \\
\hline A3 & $27.92 \pm 0.02$ & $0.632 \pm 0.002$ & $0.715 \pm 0.001$ & $1.13 \pm 0.02$ & $11.60 \pm 0.02$ \\
\hline A4 & $27.47 \pm 0.07$ & $0.589 \pm 0.001$ & $0.647 \pm 0.001$ & $1.09 \pm 0.04$ & $8.96 \pm 0.02$ \\
\hline A5 & $26.56 \pm 0.02$ & $0.561 \pm 0.002$ & $0.624 \pm 0.002$ & $1.11 \pm 0.01$ & $10.09 \pm 0.02$ \\
\hline A6 & $23.74 \pm 0.02$ & $0.543 \pm 0.001$ & $0.602 \pm 0.001$ & $1.10 \pm 0.02$ & $9.80 \pm 0.01$ \\
\hline A7 & $25.64 \pm 0.01$ & $0.518 \pm 0.001$ & $0.582 \pm 0.001$ & $1.12 \pm 0.02$ & $10.99 \pm 0.00$ \\
\hline A8 & $26.10 \pm 0.02$ & $0.482 \pm 0.001$ & $0.562 \pm 0.001$ & $1.17 \pm 0.02$ & $14.53 \pm 0.02$ \\
\hline A9 & $26.11 \pm 0.01$ & $0.561 \pm 0.01$ & $0.637 \pm 0.001$ & $1.11 \pm 0.01$ & $10.09 \pm 0.01$ \\
\hline
\end{tabular}

The prepared gastroretentive drug delivery system for raft forming tablets were characterized for angle of repose, bulk density, tapped density, carr's index and hausner's ratio which are shown in table. Angle of repose of all batches was within $23.74^{\circ}-30.96^{\circ}$, carr's index of all batches was within 8.96 - 14.53 and hausner's ratio of all batches was found within 1.091.17 which indicate good flow property of powder.

Table 4: Post-Compression Parameters of optimized batches:

\begin{tabular}{|c|c|c|c|c|c|}
\hline Formulations & $\begin{array}{c}\text { Weight Variation } \\
(\mathbf{m g})\end{array}$ & $\begin{array}{c}\text { Hardness } \\
\left(\mathbf{k g} / \mathbf{c m}^{\mathbf{2}}\right)\end{array}$ & $\begin{array}{c}\text { Thickness } \\
(\mathbf{m m})\end{array}$ & $\begin{array}{c}\text { Friability } \\
(\%)\end{array}$ & $\begin{array}{c}\text { (\%)Drug } \\
\text { Content }\end{array}$ \\
\hline A1 & $250 \pm 0.2$ & $5.9 \mathrm{~kg} / \mathrm{cm}^{2}$ & 4.5 & $0.49 \pm 0.11$ & 99.31 \\
\hline A2 & $251 \pm 0.1$ & $5.8 \mathrm{~kg} / \mathrm{cm}^{2}$ & 3.5 & $0.42 \pm 0.01$ & 98.86 \\
\hline A3 & $249 \pm 0.0$ & $5.9 \mathrm{~kg} / \mathrm{cm}^{2}$ & 4.5 & $0.41 \pm 0.00$ & 98.64 \\
\hline A4 & $251 \pm 0.3$ & $6.0 \mathrm{~kg} / \mathrm{cm}^{2}$ & 3.3 & $0.50 \pm 0.09$ & 98.02 \\
\hline A5 & $249 \pm 0.4$ & $6.2 \mathrm{~kg} / \mathrm{cm}^{2}$ & 4.2 & $0.48 \pm 0.07$ & 97.53 \\
\hline A6 & $249 \pm 0.0$ & $6.5 \mathrm{~kg} / \mathrm{cm}^{2}$ & 4.5 & $0.43 \pm 0.02$ & 97.75 \\
\hline A7 & $250 \pm 0.4$ & $6.3 \mathrm{~kg} / \mathrm{cm}^{2}$ & 4.5 & $0.41 \pm 0.00$ & 98.02 \\
\hline A8 & $250 \pm 0.2$ & $6.4 \mathrm{~kg} / \mathrm{cm}^{2}$ & 4.4 & $0.45 \pm 0.04$ & 98.41 \\
\hline A9 & $249 \pm 0.07$ & $5.2 \mathrm{~kg} / \mathrm{cm}^{2}$ & 3.5 & $0.51 \pm 0.02$ & 99.08 \\
\hline
\end{tabular}

\section{Hardness test}

The measured hardness of tablets of each batch ranged between 5.2 to $6.5 \mathrm{~kg} / \mathrm{cm} 2$ This ensures good handling characteristics of all batches.

\section{Thickness}

The measured thickness of tablets of each batch ranged between 3.3 to 4.5 this ensures good handling characteristics of all batches.

\section{Friability test}

The values of friability test of tablets of each batch ranged between $0.41-0.51 \%$ The $\%$ friability was less than $1 \%$ in all the formulations ensuring that the tablets were mechanically stable.

\section{Weight variation test}

The percentage weight variations for tablets of each batch ranged between $249-251 \mathrm{mg}$ all the tablets passed weight variation test as the $\%$ weight variation was within the Pharmacopoeial limits of $\pm 5 \%$ of the weight. The weights of all the tablets were found to be uniform with low standard deviation values.

\section{Drug content uniformity}

The percentage of drug content was found to be between $97.53 \%$ and $99.31 \%$ of It Ondansetron hydrochloride, which was within acceptable limits. The results of drug content uniformity in each batch.

Table 5: In-vitro buoyancy study of optimized batches

\begin{tabular}{|c|c|c|}
\hline $\begin{array}{c}\text { Formulation } \\
\text { Codes }\end{array}$ & $\begin{array}{c}\text { Floating Lag Time } \\
\text { (Sec) }\end{array}$ & $\begin{array}{c}\text { Total FLT } \\
\text { Hours }\end{array}$ \\
\hline A1 & $17 \pm 0.1$ & $>12$ \\
\hline A2 & $17 \pm 0.1$ & $>12$ \\
\hline A3 & $30 \pm 0.2$ & $>12$ \\
\hline A4 & $32 \pm 0.3$ & $>12$ \\
\hline A5 & $20 \pm 0.1$ & $>12$ \\
\hline A6 & $18 \pm 0.1$ & $>12$ \\
\hline A7 & $20 \pm 0.2$ & $>12$ \\
\hline A8 & $19 \pm 0.1$ & $>12$ \\
\hline A9 & $22 \pm 0.4$ & $>12$ \\
\hline
\end{tabular}

\section{Buoyancy study}

On immersion in $0.1 \mathrm{~N} \mathrm{HCl}$ solution $\mathrm{pH}(1.2)$ at $37 \mathrm{oC}$, the tablets floated, and remained buoyant without disintegration. The results of buoyancy study and showed buoyancy character of prepared tablet of formulation. Formulation shows floating lag time as $17 \mathrm{sec}$. which was less compared to other formulations. 
Table 6: Data for Raft Strength and Acid Neutralizing Capacity:

\begin{tabular}{|c|c|c|}
\hline Batch no & Raft Strength (gm) & Acid Neutralizing Capacity (mEq) $^{*}$ \\
\hline A1 & $0.58 \pm 0.1$ & $6 \pm 0.2$ \\
\hline A2 & $0.65 \pm 0.2$ & $7 \pm 0.1$ \\
\hline A3 & $0.59 \pm 0.1$ & $6 \pm 0.1$ \\
\hline A4 & $0.57 \pm 0.1$ & $6 \pm 0.0$ \\
\hline A5 & $0.59 \pm 0.0$ & $6.5 \pm 0.0$ \\
\hline A6 & $0.66 \pm 0.2$ & $7.2 \pm 0.1$ \\
\hline A7 & $0.66 \pm 0.3$ & $6.6 \pm 0.1$ \\
\hline A8 & $0.68 \pm 0.1$ & $7 \pm 0.1$ \\
\hline A9 & $0.73 \pm 0.2$ & $7.1 \pm 0.1$ \\
\hline
\end{tabular}

\section{Raft strength, Acid Neutralizing Capacity}

All the parameters are evaluated using $0.1 \mathrm{~N} \mathrm{HCl}$ in specific procedure taking 10 tablets for evaluation of both the evaluation parameter

According to data of both specific evaluation parameter of the raft forming formulation, A9 batch was having maximum raft strength, \&Acid Neutralizing Capacity range between"(6-7.2).So it was selected as an ideal formulation as raft formation tablet.

$\%$ Swelling Index of Optimized batches in graphical presentation:

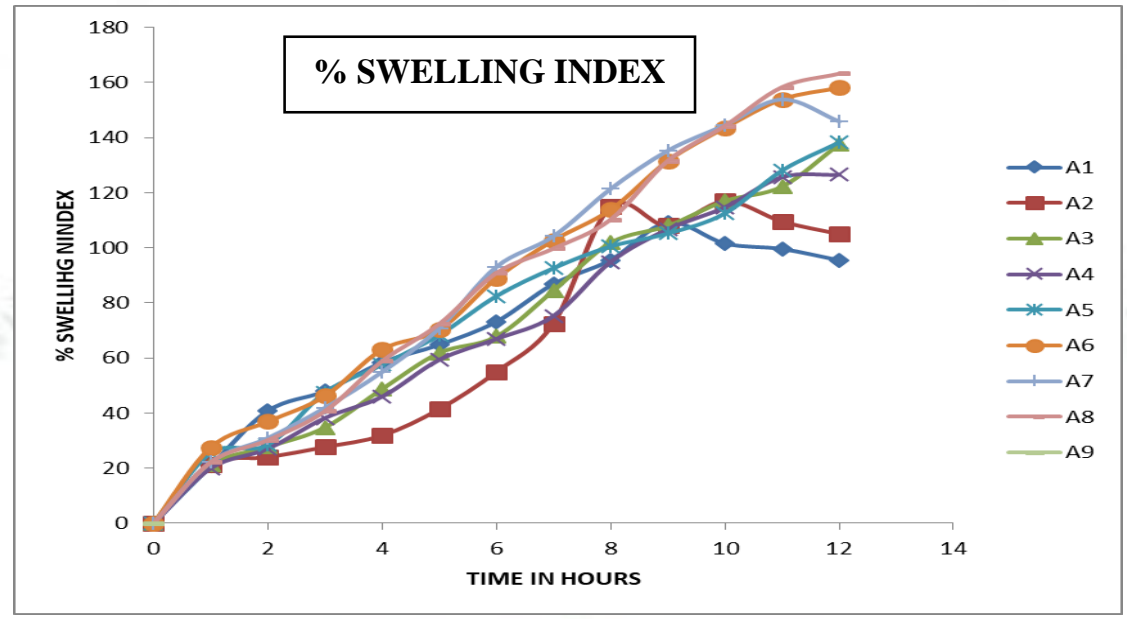

Figure 7: \% swelling index of optimized batches

\section{Swelling Index:}

Swelling index of all batches i.e. A1 to A9 is maximum $\%$ of wt. $95.5 \%, 105.01 \%, 137.65 \%, 126.53 \%, 138.30 \%$, $158.13 \%, 145.90 \%, 163.26 \%$ and 108.41 respectively. Show in figure No.7

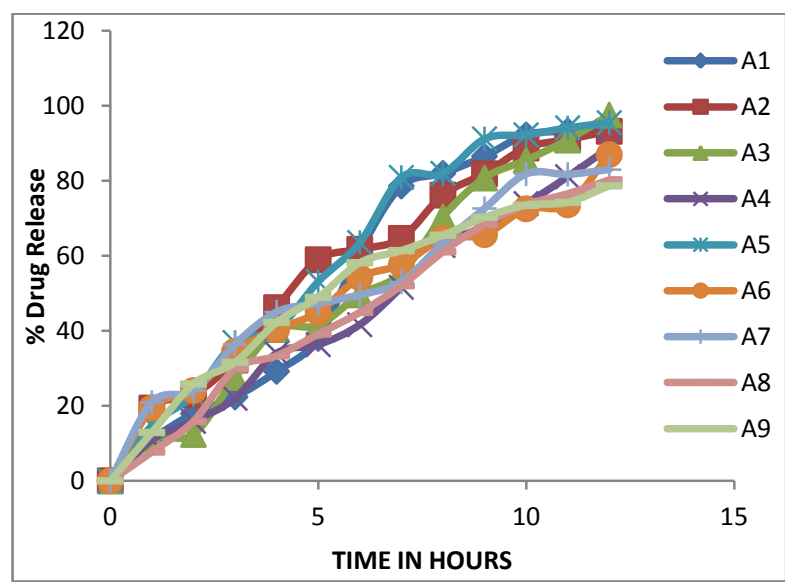

Figure 8: \%Drug Release in Graphical Presentation: (A1 to A9)

\section{In Vitro dissolution studies:}

The release rate of Ondansetron hydrochloride from floating tablets was determined using The United States Pharmacopoeia (USP) XXIV dissolution testing apparatus II (paddle method). The dissolution test was performed using $900 \mathrm{ml}$ of $0.1 \mathrm{~N} \mathrm{HCl}$, at $37 \pm 0.5^{\circ} \mathrm{C}$ and $50 \mathrm{rpm}$ A sample $(1 \mathrm{ml})$ of the solution was withdrawn from the dissolution apparatus, and volume equivalent to the amount of sample withdrawn was replaced with fresh dissolution medium. The samples were visualized on UV at $310 \mathrm{~nm}$ after appropriate dilutions. Absorbance data obtained was substituted in the equation of standard curve and values were calculated for total cumulative amount of drug released. All the nine formulation of prepared floating tablets of Ondansetron hydrochloride were subjected to in-vitro release studies these studies were carried out using dissolution apparatus, 0.1N HCL (pH 1.2)

The drug release batch A1, A2, A3, A4, A5, A6, A7, A8 and A9 were found $94.30 \%, 93.15 \%, 97.48 \%, 88.87 \%$, $95.44 \%, 86.96 \%, 82.94 \%$, and $80.22 \%$, and $78.63 \%$ respectively. 
Data analysis:

Table 7: In-vitro Drug release data Analysis

\begin{tabular}{|c|c|c|c|c|c|c|c|c|c|c|}
\hline Batch & \multicolumn{2}{|c|}{ Zero order } & \multicolumn{2}{|c|}{ First order } & \multicolumn{2}{|c|}{ Higuchi } & \multicolumn{2}{|c|}{$\begin{array}{c}\text { Korsmeyer- } \\
\text { peppas }\end{array}$} & \multicolumn{2}{|c|}{ Hixson-Crowell } \\
\hline \multirow[t]{4}{*}{ A1 } & $\mathbf{R}$ & Slope & $\mathbf{R}$ & Slope & $\mathbf{R}$ & Slope & $\mathbf{R}$ & Slope & $\mathbf{R}$ & Slope \\
\hline & 0.9512 & 8.4131 & 0.8466 & 0.0860 & 0.9612 & 39.002 & 0.9873 & 1.0206 & \multirow[t]{3}{*}{0.7144} & \multirow[t]{3}{*}{0.5168} \\
\hline & & & & & & & \multicolumn{2}{|c|}{$\mathbf{N}$} & & \\
\hline & & & & & & & 0.9307 & & & \\
\hline
\end{tabular}

\section{Data Analysis:}

The in-vitro release data was subjected to goodness of fit test by linear regression analysis according to zero order, first order kinetic equations, higuchi equation, korsmeyer-peppas and Hixson-Crowell models to ascertain the mechanism of drug release. The results of linear regression analysis of data including regression coefficient are summarized in Table 7.

When the regression coefficient ' $r$ ' value of Zero order and korsmeyer-peppas plots were compared, it was observed that the ' $r$ ' values of Zero order was found to be 0.9512 whereas the ' $r$ ' values of korsmeyer-peppas plot was found to be 0.9873 indicating drug release from optimized formulation was found to follow Korsmeyerpeppas kinetics.

The in-vitro dissolution data was fitted to Korsmeyerequation, values of exponent ' $n$ ' was found to be 0.9307 indicating that the drug release is by Anomalous transport mechanism.
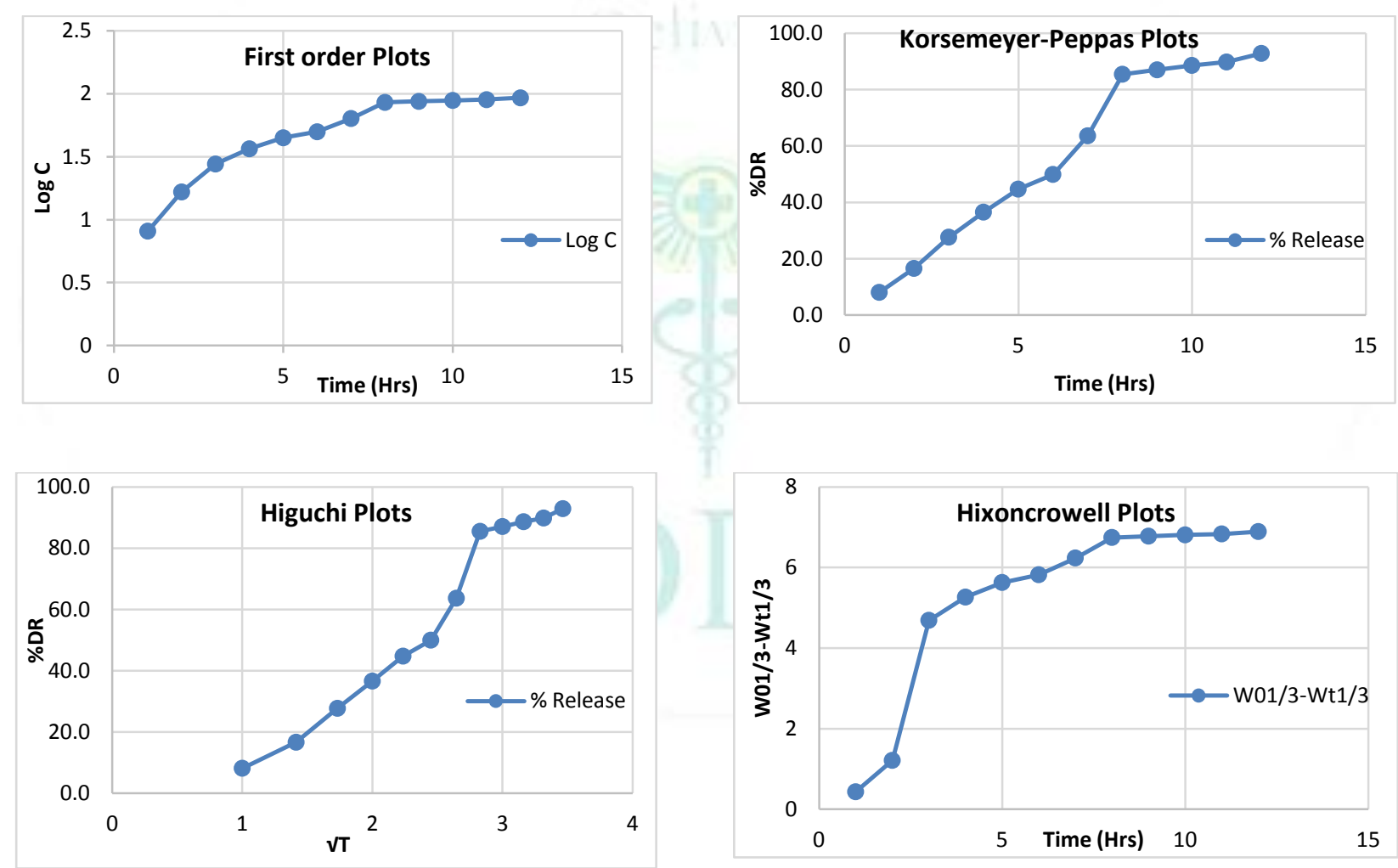

Figure 9: Release Profile of Ondansetron $\mathrm{HCl}$

Table 8: Result of ANOVA

\begin{tabular}{|l|l|l|l|l|l|l|l|}
\hline Response model & $\begin{array}{l}\text { Sum of } \\
\text { square }\end{array}$ & $\begin{array}{l}\text { Degree of } \\
\text { freedom }\end{array}$ & $\begin{array}{l}\text { Mean } \\
\text { square }\end{array}$ & F value & P value & R square & $\begin{array}{l}\text { Model } \\
\text { significant/ } \\
\text { Not-Significant }\end{array}$ \\
\hline \%drug release & 280.57 & 12 & 55.76 & 63.28 & $<0.0001$ & 0.9784 & Significant \\
\hline Raft strength & 0.0293 & 12 & 0.0049 & 7.34 & 0.0105 & 0.8399 & Significant \\
\hline
\end{tabular}



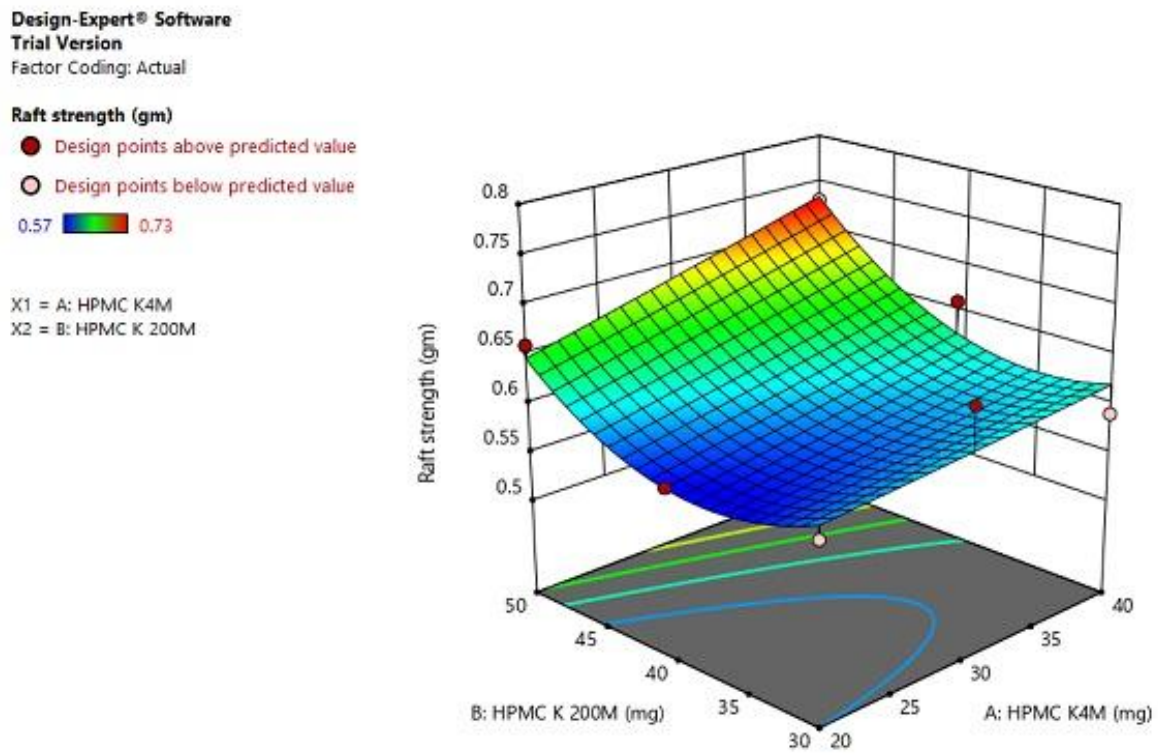

Figure 10: A response surface plot showing effect of concentration of independent variables on the Raft strength.
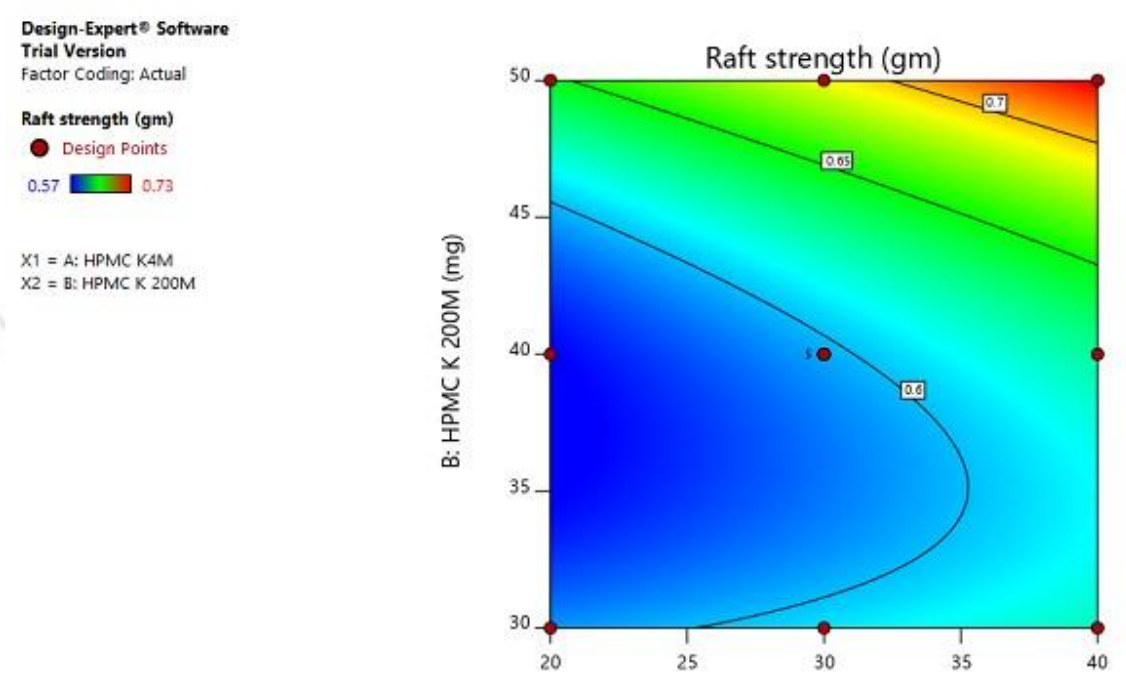

A: HPMC K4M (mg)

Figure 11: A counter plot showing relationship between various levels of independent variables to gain fixed value of Raft strength.

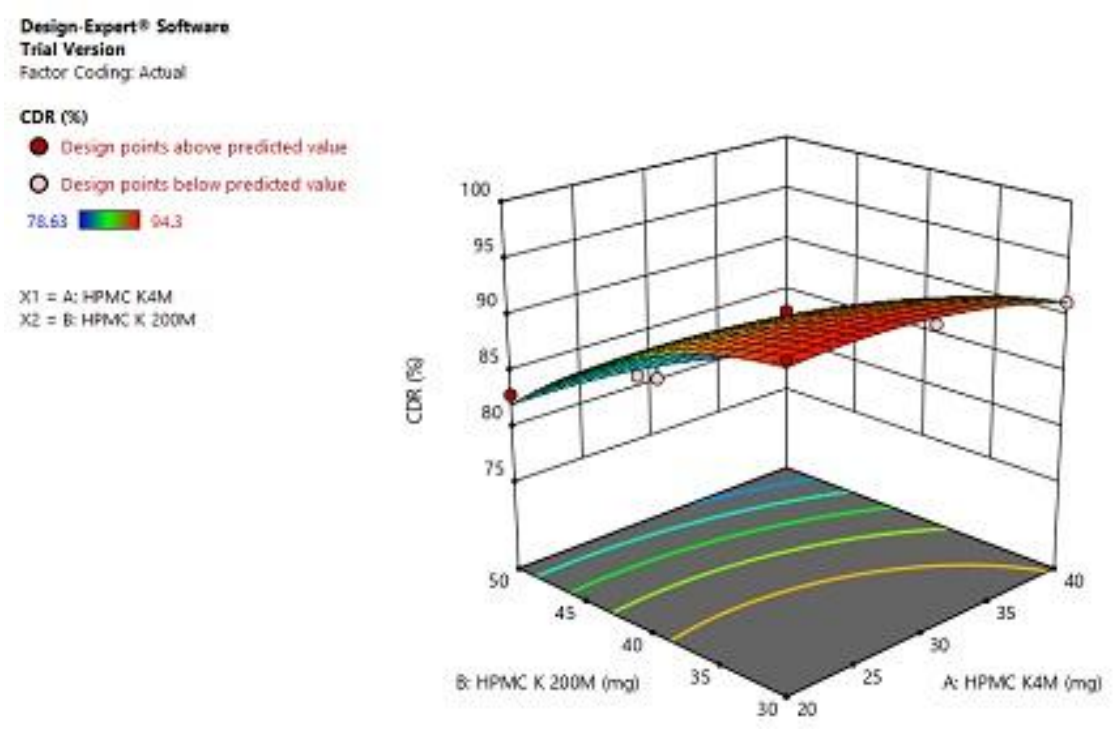

Figure 12: A response surface plot showing effect of concentration of independent variables on the $\%$ drug release 


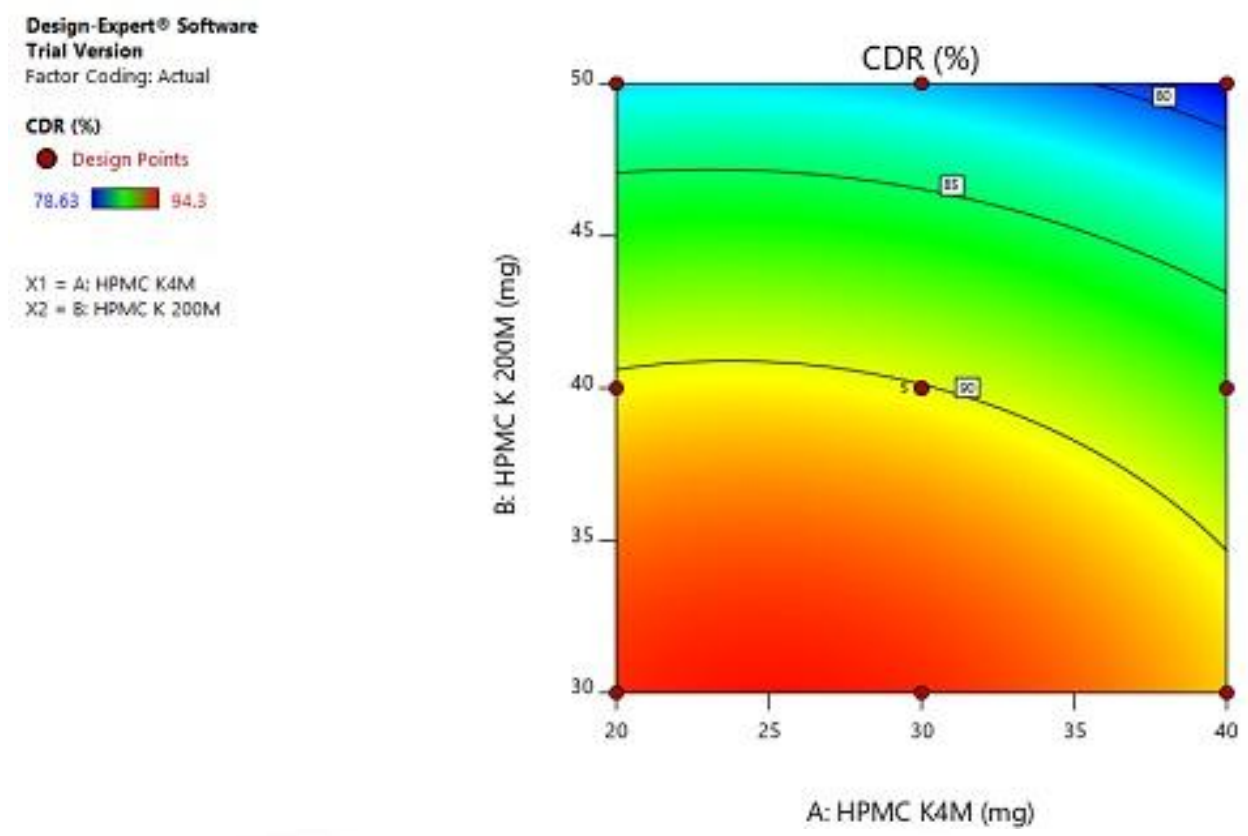

Figure 13: A counter plot of showing relationship between various levels of independent variables to gain fixed value of $\%$ drug release.

Stability Study

Table 9: Stability study of optimized formulation batch

\begin{tabular}{|c|c|c|c|c|c|c|}
\hline Condition & $\begin{array}{c}\text { Time } \\
(\mathbf{m o n t h})\end{array}$ & $\begin{array}{c}\text { Hardness } \\
\left(\mathbf{K g} / \mathbf{c m}^{\mathbf{2}}\right)\end{array}$ & $\begin{array}{c}\text { Friability } \\
(\boldsymbol{\%})\end{array}$ & $\begin{array}{c}\text { Drug } \\
\text { content }(\boldsymbol{\%})\end{array}$ & $\begin{array}{c}\text { Floating lag } \\
\text { time (Sec) }\end{array}$ & $\begin{array}{c}\text { \% Drug } \\
\text { release }\end{array}$ \\
\hline $\begin{array}{c}\text { Accelerated temperature } \\
\mathbf{4 0} \mathbf{C} \text { and 75\% } \mathbf{~ H H}\end{array}$ & 3 & 4.2 & 0.46 & 97.48 & 23 & 92.39 \\
\hline
\end{tabular}

No significance changes are observed after stability study.

\section{\%Drug Release in Graphical Presentation}

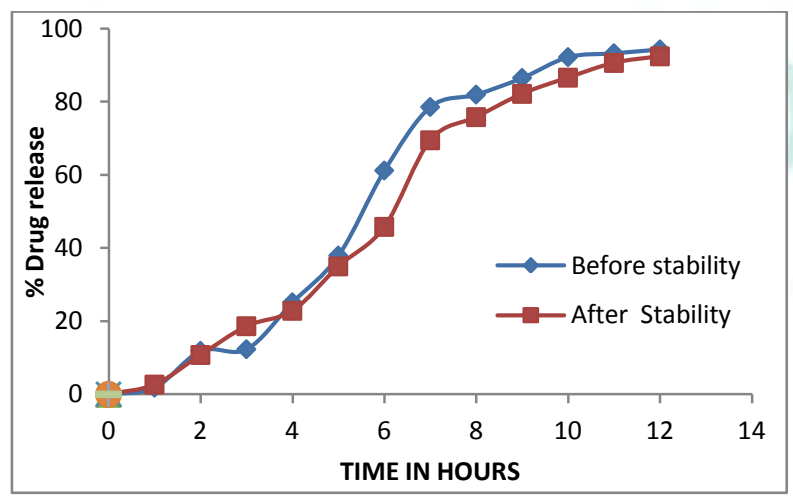

Figure 14: Stability Studies batch In Vitro \%Drug Release

\section{CONCLUSION}

Many patients are suffering from the gastro-esophageal reflux disease and this can be overcome by using raft forming floating tablet of Ondansetron hydrochloride. It was concluded that raft forming floating tablet containing HPMC K 200M, HPMC K 4M, sodium alginate and sodium bicarbonate form raft on $0.1 \mathrm{~N} \mathrm{HCL}$ which form suffering raft strength to prevent reflux of the gastric content.
The data obtained thus suggests that gastroretentive drug delivery system can be successfully designed to give controlled drug delivery, improve bioavailability and other desirable characteristics.

The present study shows that Ondansetron $\mathrm{HCl}$ can are made into floating Dosage form and raft forming by direct compression technique. Floating tablet of Ondansetron $\mathrm{HCl}$ is shorter lag time.

Ondansetron $\mathrm{HCl}$ floating tablet were prepared by direct compression technique and found to be good with chipping, capping, and sticking.

FIR and DSC study indicates no drug-excipient interaction in the formulation.

The in-vitro dissolution profile of optimized floating tablet formulated of Ondansetron $\mathrm{HCl}$ were found sustained drug release up to 12 hours and release can be extended for longer period over 12 hours by increasing the concentration of polymers.

$3^{2}$ full factional design and optimization technique successfully used in the development of floating tablet.

Comparing the all formulations, formulation A3 was considered as optimized formulation which exhibited $97.48 \%$ of drug release in 12 hours, and floating lag time of $30 \mathrm{sec}$, total floating over 12 hours. 


\section{REFERENCES}

1. Soni H, Ghulaxe C, Upadhyay S, Pillai S. Development and in vitro evaluation of an oral floating tablet of metronidazole. Journal of Drug Delivery and Therapeutics, 2018; 8(2): 83-86. doi:10.22270/jddt.v8i2.1673

2. Panda S, Sailada NS, Devi B, Pattnaik S, Maharana L, Design of Floating Drug Delivery Systems, Int. J. Pharm. Sci. Rev. Res, 2016; 39(1):125-132.

3. Iftequar S, Saifee M, Swaroop L, Zaheer Z, Meraj S, Khan F et al, Formulation and evaluation of floating drug delivery system of ramipril Journal of Innovations in Pharmaceuticals and Biological Sciences JIPBS, 2013; 3(1):85-95.

4. Patle L, Formulation and Evaluation of Ondansetron Floating Tablet Research Journal of Pharmaceutical Dosage Form and Technology. 2017; 9(4):975-437.

5. Jha P, Prajapati V, Solanki H, Jani G, Kotak U pharmaceutical aspects of various floating drug delivery system world journal of pharmacy and pharmaceutical sciences 2015; 4(4)569-589.

6. Shraddha V, Suggala PV, Gholap S, Salunke R, Jain H, Swain $\mathrm{K}$, review on: bilayer floating tablet world journal of pharmacy and pharmaceutical sciences. 2016; 5(02):14111423.

7. Kaur H, Loyee S, Garg R, Formulation and Evaluation of Gastroretentive Floating Drug Delivery System of Atenolol International Journal of Pharma Research and Health Sciences. 2016; 4(5):1371-1375.

8. Vennam S, Bhukya B, Formulation and Evaluation of Gastroretentive drug delivery system of Amlodipine Besylate Floating Tablets, Journal of drug delivery research.2014;3(1):11-21.

9. Gupta P, Gnanarajan, Kothiyal P, Floating Drug Delivery System A Review International Journal of Pharma Research, August 2015; 4(8):37-44

10. Agarwal D, Ranawat M, Chauhan C, Kamble R. Formulation and charecterisation of colon targeted ph dependent microspheres of capecitabine for colorectal cancer. Journal of
Drug Delivery and Therapeutics, 2014; 3(6):215-222. doi:10.22270/jddt.v3i6.747

11. Soni H, Patel VA, Preparation and Evaluation of Raft Forming Chewable Tablet of Ranitidine Hydrochloride. International Journal of Pharmaceutical Research \& Allied Sciences. 2016; 59(3):290-296.

12. Kumar S, Kumar A, Gupta V, Malodia K, Rakha P, Oral Extended Release Drug Delivery System: A Promising Approach Review Article, Asian Journal of Pharma Tech, April-June 2005; 2: 38-43.

13. Shaikh S, Khan GJ, Khurshid M, Ahmad S, Mohsin S, Salman S, "Floating with Bioadhesion: A Unique Expansion in GRDDS" A Review article, in AJPR, Dec 2015; 2:1-11.

14. Ratnaparkhi M. Formulation and development of floating drug delivery of Itopride $\mathrm{Hcl}$. Journal of Drug Delivery and Therapeutics, 2013; 3(4):222-228. doi:10.22270/jddt.v3i4.579

15. Panesar S, Chaturvedi S, Saini N.K, Avasthi R, Quadri SS, Singh A, Current status of the 'rule of halves' of hypertension: a survey among the residents of slum resettlement colony from east Delhi, Health line, July-Dec 2013; 4:69-73.

16. Ramanathan. M, Subramanian. L, Manikandan. S, Venkatesan. N, Dr. Solairaj. P, Gastro retentive - floating drug delivery system an overview, Asian Journal of Pharmaceutical Research and Development.2017; 5 (4):1-07.

17. Kumar R, Gupta S, Chandra A, Gautam PK, Floating tablets: a realistic approach in gastroretentive drug delivery system. International journal pharmaceutical research and bio science. 2016; 5(6):1-20.

18. Kshirsagar SJ, Wadekar SB, Gastroretentive drug delivery system of hydrochlorothiazide: formulation, optimization and in vivo evaluation, Asian Journal of Pharmaceutical Sciences 2011; 6(3-4):166-175.

19. Panigrahy Rabi N, Mahale Arun N, Dhaked PS, Formulation And In Vitro Evaluation Of Combined Floating mucoadesive Tablet of Metoprolol Succinate, International Journal of Pharmacy and Pharmaceutical Science, 2011; 3,(2):221-226. 